\title{
A Solid Structure of 2-Pyridinesulfonic Acid
}

\author{
Moon Soon Cha, Jung Woon Lee, Shin Won Kang, and Ok-Sang Jung *
}

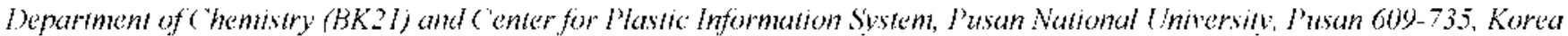 \\ "li-nail: oksimgíupusan.ac.kr \\ Recered September 2I, 2004
}

Key Words : Ambidentate ligand, Crystal structure, 2-Pyridinesullonic acid, Tautomerism

Some tautomeric ligands and their metal complexes have been attracted owing to both biological and chemical importance.' In particular, tautomeric equilibria have often been scrutinized to deduce a relationship between structure and stability, ${ }^{2--}$ and the results have been extended beyond the initial studies to such diverse areas as quantum mechanical calculations, ${ }^{5}$ molecular switches," tautomeric catalysts. ${ }^{7}$ molecular recognitions, ${ }^{8}$ and theories of genetic mutation. ${ }^{2}$ For instance, the tautomeric equilibria of punine and pyrimidine bases have been suggested to affect R.VA transcription and DNA replication in biological systems ${ }^{2}$ and behaviors of nucleic acids." lautomeric thio-bases such as thiouracil and thiocytosine are normal constituents of some t-R.VA species. "' Among such tautomeric systems, the simplest example is pyridine-2-thiolate analogs that are capable of binding to metals as either pyridine-2-thiol ( $A$, thiol) or pyridine-2-thione (B, thione) (eq 1).' Recently,<smiles>Cc1ccccc1</smiles>

A<smiles>C=CC</smiles>

B crystal structures and tautomerism of cobalt(1[I) and rhodium(III) complexes of pyridine-2-thiolate have been reported in our previous papers. ${ }^{11 \cdot 13}$

In an effort to expand the tautomeric chemistry, 2-pyridinesulfonic acid (eq 2) has been prepared and fully characterized by $\mathrm{X}$-ray crystallograply. Its behaviors including the degree of dissociation in solution have been known to be strongly dependent on substituents. ${ }^{1+}$. Moreover, 2-pyridinesulfonic acid has been employed as a bidentate ligand. ${ }^{15}$

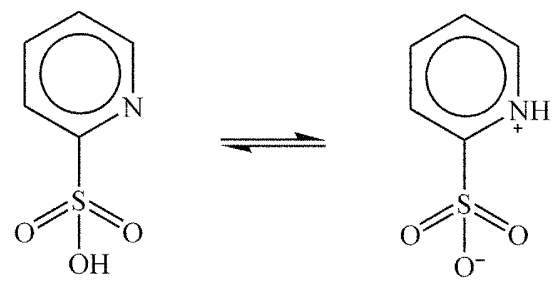

2-Pyridinesulfonic acid

\section{Experimental Section}

Reagents and Measurements. Elemental analyses were performed by the Advanced Analysis Center at KIST. The infrared spectra in the $5000-400 \mathrm{~cm}^{-1}$ region were measured as $\mathrm{KBr}$ pellets on a l'erkin Elmer $16 \mathrm{~F}$ l'C model $\mathrm{Fl}$ - $\mathrm{CR}$ spectrophotometer. 2-Pyridinesulfonic acid was smoothly prepared by oxidizing 2-mercaptopyridine with nitric acid. ${ }^{1 f_{1}}$ ${ }^{1} \mathrm{H}$ and ${ }^{1:} \mathrm{C}$ NMR spectra were recorded on a varian Gemini300 V.MR spectrometer operating at $300.00 \mathrm{MHz}\left({ }^{1} \mathrm{H}\right)$ and $75.48 \mathrm{MHz}\left({ }^{1 .} \mathrm{C}\right)$, respectively. The chemical shifts were relative to $\mathrm{SiMe}_{+}\left({ }^{\prime} \mathrm{H}\right.$ and $\left.{ }^{1 .} \mathrm{C}\right)$ as an intemal standard.

Crystallographic Structure Determination. A colorless crystal was wedged in a Lindemann capillary with mother solvent. X-ray data were collected on an Enraf-Nonius CAD4 automatic diffractometer with graphite-monochromated Mo $\mathrm{K} \alpha(\lambda-0.71073 \AA)$ at ambient temperature. Unit cell dimension was based on 25 well-centered reflections by using a least-square procedure. Data were collected $\omega / 2 \theta$ scans within the angular range 5.2-50.0 $0^{\circ}$. During the data collection, three standard reflections monitored every hour did not show any significant intensity variation. The data were corrected for Lorentz and polarization effects. Absorption effects were conrected by the empirical $\psi$-scan method. The structure was solved by the SHELXS 97 and refined by SHELXL 97. The non-liydrogen atoms were refined anisotropically, and hydrogen atoms were placed in calculated

Table 1 Crystallographic Data of 2-Pyridinesulfonic Acid

\begin{tabular}{|c|c|}
\hline formula & $\mathrm{C}_{5} \mathrm{H}_{4} \mathrm{NO}_{3} \mathrm{~S}$ \\
\hline f.w. & 158.15 \\
\hline crystal system & orthorhombic \\
\hline space group & Pbca \\
\hline a. $\AA$ & $8.117(1)$ \\
\hline$b, \AA$ & $9.723(3)$ \\
\hline$c, \AA$ & $15.640(1)$ \\
\hline$\because A^{-i}$ & $1234.3(4)$ \\
\hline Z & 8 \\
\hline$d_{j b_{i}} \mathrm{gcmn}^{-3}$ & 1.702 \\
\hline$\mu, \mathrm{mm}^{-1}$ & 0.460 \\
\hline Datairestraints parameters & $978 / 0 / 92$ \\
\hline $\mathrm{R}\{\mathrm{l}>2 a \mathrm{l})\}$ & $\begin{array}{ll}\mathrm{R}_{1} & 0.0400 \\
w \mathrm{R}_{2} & 0.1007\end{array}$ \\
\hline
\end{tabular}


positions and refined only for the isoltopic thermal factors. Crystal parameters and procedural information corresponding to data collection and structure refinement were given in Table 1.

Crystallographic data for the structure reported here have been deposited with the Cambridge Crystallographic Data Centre (Deposition No. CCDC-259642). The data can be obtained free of charge via hip: uww.ccdccum.ck uk pert catrey catreg.cgi (or from the CCDC, 12 Union Road, Cambridge CB2 15:7., UK; lax: +44 1233 336033; c-mail: deposit(docdc.cam ac.uk).

\section{Results and Discussion}

2-Pyridinesulfonic acid was recrystallized in a mixture of chloroform and $n$-hexane $(1: 1)$ to obtain single crystals suitable for X-ray crystallography. The colorless crystalline solids are soluble in polar organic solvents and are stable in solution. X-ray characterization on the single crystal has provided a confident structure. The molecular structure and packing diagram are shown in Figure 1. The compound is a discrete molecule in solid state in contrast to 3-pyridinesulfonic acid. ${ }^{18}$ The $\mathrm{C}-\mathrm{C}$ and $\mathrm{C}-\mathrm{N}$ bond lengths in the ring are in the range of $1.33 \AA-1.38 \AA$, which are similar to the corresponding lengths of gencral aromatic compounds. The $\mathrm{C}(1)-\mathrm{S}(1)$ bond length is $1.803(2) \AA$. All the $\mathrm{S}-\mathrm{O}$ bond lengths (1.436(2) $\AA .1 .439(2) \AA$, and $1.448(2) \AA$ ) do not show signilicant differences, indicating that the $\pi$ electrons around the S-O bonds are delocalized in solid state. Furthermore, such a fact implies that the protic $\mathrm{H}$ is attached to the nitrogen of 2-pyridine rather than $\mathrm{O}-\mathrm{H}$ tautomer. Thus,
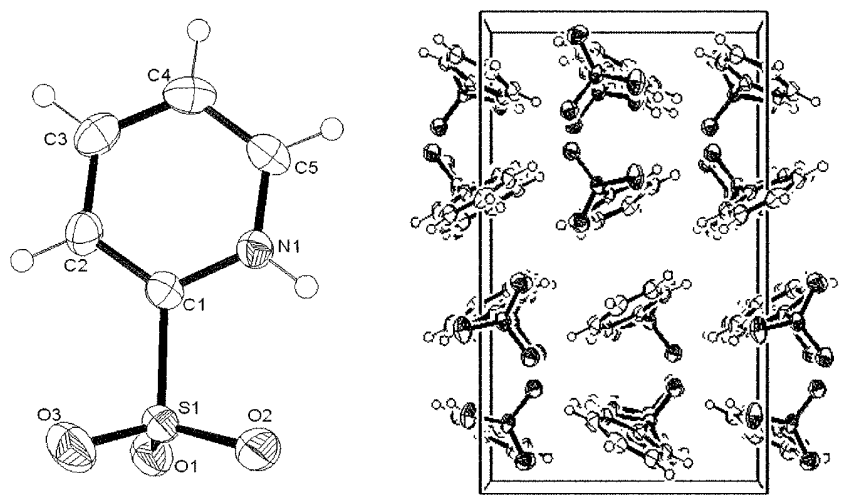

Figure 1. ORTEP view (left) and packing view (100) of 2pyridinesulfonic acid. The ORTEP is depicted in thermal ellipsoids at the $50 \%$ level<smiles></smiles>

Scheme 1

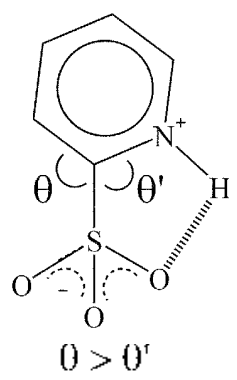

Scheme 2

Table 2. Relevant Bond Distances and Angles of 2-Pyridinesulfonic Acid

\begin{tabular}{lcll}
\hline $\mathrm{S}(1)-\mathrm{O}(3)$ & $14358(16)$ & $\mathrm{N}(1)-\mathrm{C}(1)$ & $1.346(3)$ \\
$\mathrm{S}(1)-\mathrm{O}(2)$ & $1.4391(18)$ & $\mathrm{C}(1)-\mathrm{C}(2)$ & $1.361(3)$ \\
$\mathrm{S}(1)-\mathrm{O}(1)$ & $1.4484(16)$ & $\mathrm{C}(2)-\mathrm{C}(3)$ & $1.379(3)$ \\
$\mathrm{S}(1)-\mathrm{C}(1)$ & $1803(2)$ & $\mathrm{C}(3)-\mathrm{C}(4)$ & $1.383(3)$ \\
$\mathrm{N}(1)-\mathrm{C}(5)$ & $1.330(3)$ & $\mathrm{C}(4)-\mathrm{C}(5)$ & $1.367(3)$ \\
& & & \\
$O(3)-\mathrm{S}(1)-\mathrm{O}(2)$ & $115.57(11)$ & $\mathrm{N}(1)-\mathrm{C}(1)-\mathrm{C}(2)$ & $119.89(19)$ \\
$O(3)-\mathrm{S}(1)-\mathrm{O}(1)$ & $113.04(10)$ & $\mathrm{N}(1)-\mathrm{C}(1)-\mathrm{S}(1)$ & $115.57(15)$ \\
$O(2)-\mathrm{S}(1)-O(1)$ & $113.86(10)$ & $\mathrm{C}(2)-\mathrm{C}(1)-\mathrm{S}(1)$ & $124.54(17)$ \\
$O(3)-\mathrm{S}(1)-\mathrm{C}(1)$ & $10513(10)$ & $\mathrm{C}(1)-\mathrm{C}(2)-\mathrm{C}(3)$ & $118.7(2)$ \\
$O(2)-\mathrm{S}(1)-\mathrm{C}(1)$ & $103.23(10)$ & $\mathrm{C}(2)-\mathrm{C}(3)-\mathrm{C}(4)$ & $120.4(2)$ \\
$O(1)-\mathrm{S}(1)-\mathrm{C}(1)$ & $104.37(9)$ & $\mathrm{C}(5)-\mathrm{C}(4)-\mathrm{C}(3)$ & $118.7(2)$ \\
$\mathrm{C}(5)-\mathrm{N}(1)-\mathrm{C}(1)$ & $122.39(19)$ & $\mathrm{N}(1)-\mathrm{C}(5)-\mathrm{C}(4)$ & $119.8(2)$ \\
\hline
\end{tabular}

jts structure can be summarized in the following resonance structures (Scheme 1). For the structure, an intramolecular $\mathrm{N}-\mathrm{H} \cdots \mathrm{O}$ hydrogen bond $(2.33 \AA$ : the angle of $\mathrm{N}-\mathrm{H} \cdots \mathrm{O}-$ $\left.110.6(2)^{\circ}\right)$ exists in solid state. The hydrogen bond may result in an unsymmetrical bent conformation $\left(\theta>\theta^{\prime}\right)$, that is, the angle of $\mathrm{S}(1)-\mathrm{C}(1)-\mathrm{N}(1)\left(115.6(2)^{\prime)}\right)$ is some or less contracted whereas the angle of S(1)-C(1)-C(2) $\left(124.5(2)^{3)}\right)$ is concomitantly splayed out as shown in Scheme 2. Such a bent confonnation did not exist in 3-pyridinesulfonic acid." IR spectrum shows a strong broad band around $3000 \mathrm{~cm}^{-1}$ presumably owing to the $\mathrm{N}-\mathrm{H}$ bond. In contrast, the conesponding band does not appear in a simple sulfonic acid withoul pyridine moiety." Furlhermore. the crystal discrepancy factor $(\mathrm{R})$ of $\mathrm{N}-\mathrm{H}$ tautomer is more reasonable than that of $\mathrm{O}-\mathrm{H}$ tautomer $(\mathrm{R}=0.0449)$. Of course, the chemistry in solution may be different from that in the solid state.

In conclusion, the structure of 2-pyridinesulfonic acid has been litly characterized to be a $\mathrm{N}-\mathrm{H}$ taulomer rather than an $\mathrm{O}-\mathrm{H}$ tautomer. Thus these structural facts should be considered when this compound is treated as an ambidentate ligand in solid state and in solution.

Acknowledgment. Support for this research was provided by the Universily IT Research Center Project in Korea.

\section{References}

1. (a) Deeming, A. J.; Hardcastle, K. I.; Meah, M. . .; Bates, P. A.; 
Dawes. H. M.: Hursthouse. M. B. J. Chem. Soc. Dalton Trans. 1988. 227. (b) Constable. E. C.: Palmer. C. A.: Tocher. D. A. Inorg. Chim. Acta 1990. 176. 57. (c) Yap. G. P. A.: Jensen. C. M. horg. (Chem. 1992. 31, 4823. (d) Reynolds, J. G.: Sendlinger. S. C.: Murray A. M.: Huffman. J. C.: Christoll. G. Inorg. Chem. 1995, 3f, 5745. (e) Jung, O.-S : Park. S. H.: Lee, Y.A.: Cho, Y: Kim. K. M.: Lee. S: Chae. H. K: Solnn. Y. S. Inorg. Chem. 1995. 35. 6899. (f) Kettler. P. B.: Chang. Y: Rose. D.: Zubieta. J.: Abrams. M. J. Inorg. Chim. Acta 1996. 2ff. 199. (g) Chen. Y: Lin. F.: Shephered. R. E. Inorg. Chim. Acta 1998. 268. 287.

2. Beak; O.; Fry Ir.. F. S; Lee, I; Steele. F. J. Am. Chm. Soc. 1976. 98. 171 .

3. Ozeki. H.: Cockett. M. C. R.: Okuyama. K.: Takahashi. M.: Kimura. K J. Phys Chent 1995 99.8608

4. Curlev: K. Pratt R. F. J. Org. Chem. 1997. 62, 4479

5. (a) Wang I.: Bovd. R. I. J. Phys. Chem 1996, 100, 16141. (b) Broo, A.: Pearl . G.: Zenner. M. C. J. Phys. Chem. A 1997, 101. 2478 .

6. (a) Jung. O.-S.: Pierpontt. C. G. J. Am. Chem. Soc. 1994. 116. 1127. (b) Gütlich. P.: Dei. A. Angew: Chem. Int. Ed. Engt. 1997. 36. 2734

7. (a) Rony; P: Neff. R. O. J. Am. Chem. Soc. 1973, 95. 2896. (b) Bernadou, J: Fabiano, A. S: Robert, A.: Bernard. M. $J$. Am. Chem. So. 1994. 116.9375.

8. Hernandez. B.: Orozco. M.: Luque. F. J. J. Comput - tided Mol.
Des. 1997. 11. 153

9. (a) Cieplak. P.: Bash. P.: Singh. U. C.: Kollmant. P. A. J. Aint Chent. Soc. 1987. 109.6283. (b) Cramer. C. J.. Trullar. D. G. J Am. Chem. Soc. $1991,113,8552$.

10. (a) Carbon, J. A.: Hung L.; Jones, D. S. Proc. Nat Acad Sci U.S.A. 1965. 53.979. (b) Carbon, J. A.: David. H.; Studier, M. H Science 1968. 161.1146.

11. Jung. O.-S.: Kiml. Y. T.: Lee. Y.-A.: Chae. H. K. Bull. Konean Chent Soc. 1998. 19.286

12. Jung, O.-S.; Kim, Y. T.: Kim. Y. J.: Chon, J. K.; Chae. H. K. Bull. Korean Chem. Soc. 1999. $20,648$.

13. Jung. O.-S.: Lee. Y.-A.: Kim, Y. T: Chae, H. K. horg. Chim .Acta 2000. 299. 100

14. Evans. R. F.: Brown. H. C. J. Org. Chen, 1962. 27.3127

15. (a) Murata. M.: Kojima. M.: Hioki. A.: Miakawa. M.: Hirotsu. M:- Nakajima, K.: Kita, M:- Kashino. S.: Yoshikawa, Y. Coord. Chem. Rev. 1998. 17t. 109. (b) Lobana. T. S.: Kinoshita, I: Kimura. K. Nishioka. T.: Shiomi. D.; Isobe. K. Ew: J. Inorg. Chent. 2004. 356

16. Evans. R. F.: Brown. H. C. J. Org. Chem, 1962. 27. 1329.

17. Sheldrick. G. M. SHELAS-97: A Progrant for Stmacture Deterntnation: University of Göttingen: Germany. 1997; Sheldrick, G. M. SHELLZ-97; A Program for Stwatwe Refmement, University of Göttingen: Germany, 1997.

18. Chindrasekhar. K. Acta Chst. 1977. B33. 143.

19. Aldrich IR Spectra 13.507-3. 